\title{
FATHER STEFAN WYSZYŃSKI'S STAY WITH THE ZAMOYSKI FAMILY IN KOZŁÓWKA: A RECONSTRUCTION OF EVENTS AND PLACES*
}

The only historic-house type museum in the Lublin region - the Zamoyski Museum in Kozłówka is housed in a grand palace, which, by sheer miracle, survived along with most of the collections, in a fairly good shape, until the end of World War II. Pursuant to the land reform decree, the Kozłówka palace and park complex became the property of the state treasury in 1944 and became the first Polish museum after the German occupation. However, its subsequent post-war fortunes were not so favourable. At the end of the 1940s, a public school and an orphanage were located in the palace outbuildings (Szczepaniak 14; "Historia muzeum" [History of the museum]). As Krzysztof Kornacki writes, "The palace carpets were carried away to furnish the offices of the Provincial National Council in Lublin towards the end of the 1940s. Only one has survived - in tatters. The fate of the impressive collection of pelmets and curtains covering the windows and doors of the lounges is also disheartening. Only the ballroom set has survived in its entirety, as it was accidentally salvaged in the warehouse of the

Dr. habil. Agnieszka Bender - The John Paul II Catholic University of Lublin, Faculty of Humanities, Institute of Art Studies, Department of History of Medieval and Modern Art; correspondence address: Al. Racławickie 14, 20-950 Lublin; e-mail: agbender@kul.pl; ORCID: https://orcid.org/0000-0002-0432-7436.

Dr hab. AgNieszKa Bender - Katolicki Uniwersytet Lubelski Jana Pawła II, Wydział Nauk Humanistycznych, Instytut Nauk o Sztuce, Katedra Historii Sztuki Średniowiecznej i Nowożytnej; adres do korespondencji: Al. Racławickie 14, 20-950 Lublin; e-mail: agbender@kul.pl; ORCID: https://orcid.org/0000-0002-0432-7436.

* I would like to thank everyone who helped me with collecting information and materials for this article: the Director of the Zamoyski Museum in Kozłówka Anna Fic-Lazor, former Director Krzysztof Kornacki, Grażyna Antoniuk from Department of Education, Museum Information and Publishing House, and former chief stock taker Róża Maliszewska. I also express my deep gratitude to Prof. Anna Łosowska and Canon Józef Chorębała for providing the source material. 
Wawel National Art Collection. Most of the remaining ones were cut up to make museum slippers at the request of the then director of the Lublin Museum, who held substantive supervision over Kozłówka. And the consent thereto was granted by the Ministry of Culture and Art!" (Kornacki 17). At that time, vocational training courses, scout camps and "fun events" were organized in the museum halls (Sulowski 36). In the early 1950s, the museum staff consisted of only two people - the caretaker and his wife. "It was at that time that the collection of nearly 5,000 perforated rolls for organola and pianola melted down to 1,500. And despite the fact that it is the largest in Poland and one of the largest in the world, [Kornacki adds] sadly, that the missing 3,500 rolls went through the chimneys of the palace stoves, serving as a good tinder" (Sulowski 139). In 1955, the Central Museum Depot of the Ministry of Culture and Art was established in the palace. The building and its surroundings, however, continued to gradually deteriorate. Despite several attempts to compile an inventory of the collections, part of them was further dispersed (Marciszuk 8-9).

Better fortune began to favour the palace starting with the end of 1970s. In 1977, the then manager of the depot brought about the reactivation of the museum in Kozłówka, with an exhibition of historical interiors from the turn of the 19th and 20th centuries. Two years later, in 1979, Krzysztof Kornacki, a graduate of the Nicolaus Copernicus University in Toruń, museologist and historical expert, became the director of the institution, and had the first full inventory of the collection compile right from the start (Kornacki 18; "Historia muzeum" [History of the museum]). He also started renovating other buildings of the complex. Soon the following were renovated, among others: the theatre room, where a conference and exhibition room was set up, followed by the former carriage house and stables (Sulowski 36; "Historia muzeum" [History of the museum]). In order to recreate the palace interiors from the turn of the 19th and 20th centuries, the Management and specialised staff of the museum undertook numerous actions aimed to supplement the exhibits through recovery, obtaining donations and transfers from customs offices and depots. However, the most important measures were the purchases of valuable artefacts on the antiquarian market, carefully selected in terms of style, in the spirit of historicism and eclecticism (Marciszuk 8-9). The palace and park complex began to regain its former splendour, and Polish and international prestigious awards and distinctions started to pour in ("Historia muzeum" [History of the museum]). 
As Director Krzysztof Kornacki recalls, in 1990 Kozłówka was, for the first time after the war, visited by the eldest son of the last owners, Adam Marcin Zamoyski (1926-1998), who, admiring the condition of all the exhibitions, is said to have stated that he was pleasantly surprised and that everything looked the way it used to, if not even much better than in his childhood (Sulowski 36; “'Kozłówka dla zakochanych”" ['Kozłówka for lovers']). At that time, he is also said to have confirmed the fact that Fr. Stefan Wyszyński had a hideaway in the palace over the period of 19401941. He recalled that as a teenager, he would set in motion the bellows in the pipe organ during masses celebrated by Fr. Wyszyński in the palace chapel. He emphasized that the future Primate of Poland inspired universal respect and seriousness (Niezwykty Gość 9).

Over a long post-war period, conducting in-depth historical research, especially one concerning the Church, landed gentry and the Home Army (WWII Polish partisan forces; Polish abbreviation: AK), was very limited by the communist authorities, or even made impossible. All publications were subjected to thorough censorship. Thus, the wartime fate of the Primate remained almost completely unknown for a long time. The first biographies of Cardinal Wyszyński were published outside Poland. The earliest publication in this regard was a series of six volumes by Peter Raina, entitled Stefan Kardynat Wyszyński Prymas Polski [Cardinal Stefan Wyszyński, Primate of Poland], the first part of which was published in 1979 in London. The author of this very extensive work devoted only half a page to Fr. Wyszyński's oneyear stay in Kozłówka (Raina vol. 1 88-89). Another book, entitled Kardynat Wyszyński. Prymas i mąz stanu [Cardinal Stefan Wyszyński: Primate and Statesman], published in Paris in 1982, was written by Andrzej Micewski, who also described the future Primate's stay in Kozłówka in a few sentences (Micewski 33). Undoubtedly, Micewski must have known Raina's work, because the information he included about being a guest of the Zamoyski family does not actually differ from that provided by the Indian researcher. Moreover, Micewski replicated Raina's mistake, calling the owner of Kozłówka, Aleksander (Leszek) Zamoyski (1898-1961), by the name Andrzej. It is worth mentioning here that these two important biographies of the Primate were virtually unavailable in Poland at the beginning of the $1980 \mathrm{~s}$. Such publications found their way illegally from the West to a few historians and journalists, most often through private contacts. Stefan Wyszyński's stay in Kozłówka is described in greater detail by Ewa Czaczkowska (65-66). 
The author of what appears to be the earliest published war memoirs from Kozłówka was Zofia Czacka (1909-1991), the daughter of Tadeusz and Helena of Poryck (now Ukrainian Pavlivka) in Volhynia. Her father was the brother of Mother Elżbieta Róża Czacka (1876-1961) from Laski, the founder of the Congregation of the Franciscan Sisters, Servants of the Cross. Their ancestral residence was burned down, so they stayed with the Zamoyskis living on their charity. Zofia served as the head servant and was in charge of housekeeping in the palace. Her memoirs appeared in 1981, not by accident, on the pages of the theological and scientific journal Ateneum Kaplańskie. Over the period of 1932-1939, its chief editor was, after all, Fr. Stefan Wyszyński. Undoubtedly, however, the circle of the recipients of these first memoirs by Zofia was neither numerous nor diverse at that time (Czacka vol. 2 321-327).

The Primate himself, somewhat puzzlingly, wrote very little about his stay in Kozłówka, mostly on the occasion of addressing other topics. Probably the first time he mentioned "endless discussions" in Kozłówka was in the publication Nasz Ojciec Ksiadz Władystaw Korniłowicz [Our Reverend Father Władysław Korniłowicz], which came out in 1980 (Wyszyński, Nasz Ojciec 51).

Therefore, gradually, almost half a century after the war, the knowledge of Fr. Wyszyński's stay on the Zamoyski estate, lasting over a year, began to slowly expand. Here, it is worth mentioning a publication relevant to this topic, written by another witness to the wartime fortunes of Kozłówka Jadwiga Zamoyski's brother Antoni Belina Brzozowski (1914-1995), entitled Kozłówka w moich wspomnieniach [Kozłówka in my memories], which was published in 1998.

The then director of the Kozłówka museum, Krzysztof Kornacki, does not remember exactly when the idea of commemorating the figure of the Primate of the Millennium appeared (Report on the conversation with K. Kornacki). However, as a long-time museum employee Grażyna Antoniuk notes, it took about two years of preparation and detailed queries, which began around 1998. The intention was to organize the ceremony and prepare the publication for the sixtieth anniversary of the arrival of Fr. Wyszyński to Kozłówka, which fell on the year 2000 (Report on the conversation with G. Antoniuk). Undoubtedly, the initiator of actions in this direction was Róża Maliszewska, the chief stock taker of the Zamoyski Museum, who, however, stated some years later that she was unable to indicate more precisely when the above-mentioned project was conceived (Report on the conversation with 
R. Maliszewska). The enormous commitment of her and the Museum Director to this cause contributed to the solemn unveiling of the bust and the dedication plaque on June 9, 2000, commemorating the figure of Primate Stefan Wyszyński and his stay in Kozłówka during the German occupation (Antoniuk 96). It was performed by Archbishop Józef Życiński, Metropolitan of Lublin, and Jadwiga (Inka) Zamoyski, living in Canada, the youngest daughter of the last owners of Kozłówka. Placed on the façade of the palace chapel, the bust was crafted according to the design of the renowned sculptor and medal-maker Anna Wątróbska-Wdowiarska. The work was created thanks to the generosity of numerous Founders. As Director Kornacki recalls, obtaining funds required a lot of efforts. This included making commemorative medals - donation certificates, with which he himself travelled and raised money. It was not until a meeting with Zdzisław Pacan, Regional Director of PZU S.A. in Lublin, and his considerable assistance that the required sum was obtained (Report on the conversation with K. Kornacki).

The ceremony of unveiling the bust was accompanied by the museum's publication Niezwykly Gość [Extraordinary Guest], containing memories of the extraordinary guest hosted by Jadwiga and Aleksander Zamoyski. This seventy-seven-page book was edited by Krzysztof Kornecki, and the material was elaborated by Grażyna Antoniuk and Róża Maliszewska. It makes use of previously published memoirs by Zofia Czacka and Antoni Belina Brzozowski, among others, and includes texts by witnesses to the future Primate's stay in Kozłówka during the German occupation, specially prepared for the occasion, by Michał Żółtowski (1915-2009), Monika Znamierowska-Kozik, Krzysztof Znamierowski - the children of Prof. Czesław Znamierowski (1888-1960), and also by Wiktor Jaśkiewicz (1912-2003), the Professor's assistant. All these testimonies are invaluable, reminding us of the dramatic fate of the country and of the young priest Wyszyński, who was already held in high esteem. Thanks to these memoirs, the knowledge of the future Cardinal and Primate's stay at Kozłówka, as a hiding place, for over a year, was significantly supplemented and expanded. It was literally the last moment to acquire it. Now, more than twenty years later, it is particularly clear how important this initiative was.

Since the publication of this work, only limited information has been added to the attempt of reconstructing the events related to the Kozłówka episode of the Primate of the Millennium. It is worth mentioning here the Testimony of Fr. Cardinal Józef Glemp, Primate of Poland (1929-2013), 
published in 2010. Primate Wyszyński's successor stressed that in the memories of his great predecessor "Kozłówka was important," and "the palace became a shelter, but also a centre of religious and social thought" (Glemp 62). Primate Glemp also stressed that Fr. Wyszyński often "talked about conversations with Jadzia (Zamoyska)" - Jadwiga née Belina Brzozowski (1908-1998), who "appears as a woman with extraordinary abilities and a good, sensitive heart" and a person who "understood the need for social changes, a different relationship to families in 'czworaki' (manor staff quarters)." The young Fr. Wyszyński was already then said to believe that "changing the social system after the war is necessary" (Glemp 62).

In the context of supplementing the published memories, one should also mention a few radio programs and a text by Piotr Szymon Łoś entitled "Pod gościnnym dachem Zamoyskich. Kozłówka w latach okupacji” [Under the hospitable roof of the Zamoyski family: Kozłówka during the occupation], posted on the website. ${ }^{1}$ The most extensive memories, containing a lot of detailed information, are the recounted memories of Michał Żółtowski, son of Jan, owner of Czacz and other estates in Greater Poland. Their author confirmed, inter alia, that "In Kozłówka the secret teaching of young people was at full swing. The Znamierowski family and Fr. Prof. Wyszyński played the main role in it. The young participants passed their final secondary school exams before the commission from the former Lublin board of education, which came from Lubartów" (Łoś). Michał Żółtowski also recalled the words of his father, Jan, who often engaged in discussions with the future Primate. After one such conversation, he was to say with appreciation to his relatives: "To my mind, this priest seems to be the first candidate for a bishop in Poland"; the next day, in another group, he added: "This priest will still make a great career." These opinions reached Jadwiga Zamoyska, who is said to have fully confirmed them, expressing her great respect for Fr. Wyszyński (Łoś).

The next step taken by the management and employees of the Zamoyski Museum to commemorate Primate Stefan Wyszyński was the reconstruction of his room. It was the initiative of the Museum Director, Anna Fic-Lazor (director since 2015), culminating in the ceremonial opening of the new exhibition "Reverend Stefan Wyszyński in Kozłówka 1940-1941" on June 21, 2016. The honorary patronage over this event was assumed by Archbishop Stanisław Budzik, Metropolitan of Lublin, who also presided over the Holy Mass in the palace chapel ("Pokój księdza Stefana Wyszyńskiego").

\footnotetext{
${ }^{1}$ The author supplemented the text on 20.06.2020.
} 
Fr. Stefan Wyszyński, wanted by the Gestapo, was hiding on the estate of the count Zamoyski for exactly thirteen occupation months - from August 1, 1940 to September 1, 1941.

During this time, he changed rooms three times. At the beginning he lived in the northern outbuilding on the ground floor, and his neighbour was Prof. Czesław Znamierowski with his family. The remaining rooms of the outbuilding were occupied by German officers (soldiers were stationed in the ballroom and theatre hall). However, along with the growing number of the stationed occupation troops, Fr. Wyszyński moved to a room adjacent to the palace chapel. It was not convenient, however, as it did not have a separate entrance. It was possible to enter it either through the chapel, which was closed outside the time of religious services, or through the room of the Znamierowski family, who had been transferred, to this part of the palace. These inconveniences made Fr. Wyszyński change his lodgings again, and he moved "to the opposite side of the main building top floor, where he took a small room with a window overlooking the passage between the lawn and the park. He stayed in this room until his departure" (Niezwykly Gość 40). ${ }^{2}$

The museum exhibition was organized in the second room occupied by the Reverend, the one which is entered from the palace chapel, turning left immediately after entry. This decision was influenced by practical reasons, i.e. easy access to the room for tourists visiting the Zamoyski Museum (Report on the conversation with G. Antoniuk). The reconstruction of the room was not an easy task for the museum staff, as no photos of the room survived, and neither did any items associated with Fr. Wyszyński, except for two letters from the post-war years addressed to Jadwiga Zamoyska. Truly invaluable was the assistance of Prof. Znamierowski's children, Monika and Krzysztof, who together with their parents occupied a palace room sharing a bathroom with Wyszyński's and visited Reverend for religion lessons. Their accounts allowed for the reconstruction of the interior, which was the basis for the development of the script by Anna Szczepaniak and the exhibition design prepared by Przemysław Alchimowicz. Furniture from the 19th and early 20th centuries, similar to the furniture pieces in the accounts of the Znamierowski siblings, was found in the museum depot. These are: a narrow bed, small, single-door wardrobe, étagère, bedside table, desk with an armchair, kneeler, chair, wooden coat stand and a correspondence binder (Antoniuk 96). Gilded and profiled curtain rails have been hung over both windows. All these pieces of equipment, of fairly simple form, are Polish

\footnotetext{
${ }^{2}$ These are the memories of Monika Znamierowska-Kozik. See Byzdra-Kusz 60.
} 
products and mostly come from the old collections of the Zamoyski family. ${ }^{3}$ The room is also decorated with several paintings. Above the bed, in accordance with the siblings' account, a simple cross has been hung (donated by Bogusława and Andrzej Madejski) and a painting of Virgin Mary. The childhood memory did not record exactly what painting it was. The one that was placed has been associated with Kozłówka for years and represents 'Our Lady of Kodeń.' It was given in 1877 to Aniela Zamoyska née Potocki, wife of the first Entail Holder, Konstanty, by Fr. Walenty Baranowski, Bishop of Lublin ("Matka Boska Kodeńska"). Two large paintings have been hung on the wall opposite the entrance. One depicts the 'Adoration of the Madonna' and was created in northern Italy at the turn of the 16th and 17 th centuries ("Adoracja Madonny"). The other canvas, depicting 'Christ on the cross,' comes from the 17th century, probably from an Italian or Spanish workshop. ${ }^{4}$ Noteworthy are also the items placed on the desk. On the left side there is a painting of 'Our Lady of Częstochowa,' gifted by the Primate to the Brzozowski family, made available by Ewa and Antoni Brzozowski. Next to it are placed the letters written by Fr. Wyszyński to the mother of the last owner of Kozłówka, Izabela Brzozowska (1877-1960). There is also a Cyma brand travel alarm clock, which the Primate always carried with him, and a set of Pelikan brand stationery. On the desk there is a breviary with a paper picture of Saint Cecilia, with a dedication to Fr. Wyszyński, gifted by sisters Teresa Landy and Nulla Westwalewicz in Kozłówka, on the 27 th of June, 1941. The books, which were used by the Kozłówka guest, borrowed from Laski again after seventy years, have been placed on the étagère (Antoniuk 96-97). On the coat stand and in the wardrobe, a cassock, a few old cotton surplices, abundantly decorated with embroidery and lace, and a white chasuble from Nasutów, decorated with embroidery techniques have been hung. Monika and Krzysztof Znamierowski, seeing the final effect of the reconstruction, stated that the arrangement of the room was very similar to the one they remembered (Report on the conversation with G. Antoniuk).

As mentioned above, thanks to the inquiries and numerous activities undertaken by the management of the museum in the late 1990 s, it was possible to reconstruct many facts and gain a lot of knowledge about the time spent by Fr. Wyszyński in Kozłówka. The future Primate found himself in Kozłówka thanks to the initiative of his confessor and spiritual guide,

\footnotetext{
${ }^{3}$ All these objects possess museum cards asigned to them, for which I thank Mrs. Grażyna Antoniuk.

${ }^{4}$ Information from the object's card (the author was not signed).
} 
Fr. Władysław Korniłowicz (1884-1946), who proposed that he be the chaplain for twenty-two Franciscan nuns previously placed on the Zamoyski estate, with whom came a group of fifteen blind girls from the Society for the Care of the Blind in Laski. Fr. Wyszyński had a stay filled with numerous activities right from the very beginning. "He stood out by dint of wasting no time and serving with whatever he had." ("Służył tym, co miał"). He held lectures on Catholic social science and canon law for nuns who were to continue their theological studies on several levels. The displaced landowners, soldiers, artists and professors with their families hiding at the Zamoyskis' household, for whom the possibility of intellectual and spiritual development was important in these dramatic conditions, soon began to join scientific meetings, which they dubbed 'Kozłówka Academy.' As has already been mentioned, the Reverend Professor taught religion and Latin to the youth staying with the Zamoyskis on clandestine courses. In the evenings, he stayed in his room, did scientific work and wrote a lot. In the palace chapel, he held masses, rosary, May, and June devotions, heard confessions, and conducted teachings and retreats. First, the faithful from nearby villages came to Kozłówka, and eventually even those from the farthest corners of the entail; they sought advice and encouragement in the sermons from the admired and respected priest. Often, Fr. Wyszyński's pastoral ministry was also performed in the area, holding masses and hearing confessions, among others, in the nearby Kamionka Lubartowska, in which there was a parish where, in April 1940, Fr. Michał Słowikowski became the parson, replacing Fr. Piotr Gintowt murdered by Germans in January (Antoniuk 95-97; Byzdra-Kusz 60-61; "Ks. prałat M. Słowikowski”). Fr. Wyszyński, on June 13, 1941, during the indulgence of Saint Anthony, delivered a solemn sermon. Afterwards, in nearby Bełżyce, he met the rector of the Catholic University of Lublin, Fr. Antoni Szymański (1881-1942) to discuss the organization of clandestine teaching at the university (Świerdzewska). Fr. Wyszyński also visited Starościn and Amelin located within Kamionka commune ("Historia parafii ... w Starościnie" [History of the parish... in Starościn]).

The future Primate was perfectly aware of the political situation at that time. He said that the WWII

differs significantly from the old ones. The struggle is conducted not on the front lines, but throughout the country. The Germans set themselves the task of exterminating the entire Polish nation and are striving to do so through - as he put it - biological attrition. Hence, the methods of fighting have changed and entitle 
Poles to use "necessary defence," just like when being assaulted by a bandit. (Niezwykty Gość 40) ${ }^{5}$

Fr. Stefan Wyszyński regularly travelled to Nasutów, one of the entail's granges, where he celebrated masses in the local Chapel next to the palace at eight on Sundays and holidays (Ocalić od zapomnienia 184). ${ }^{6}$ These trips were surrounded by a certain amount of secrecy, as the masses were attended by partisans in addition to the entail farm hands. Although the later Primate was a soldier of the Home Army (AK) during the German occupation, his links with the Home Army are still little known, and there are many unknowns and facts to be completed (Jedynak 25-26). The short note left by Mrs. Bronisława Gliwka from Nasutów, in which she claims that for seven weeks from "the last week of May 1942," she rented one room to a man and two women who prayed every day, is not entirely clear. The woman only found out during a pastoral visit that her guests were Fr. Stefan Wyszyński with his sister and stepmother (Ocalic od zapomnienia 185). The question remains, however, whether this seven-week stay did indeed take place in 1942 or whether it happened a year earlier. On the Nasutów parish website, the date 1941 is given for this event ("Historia [parafii ... w Nasutowie]" [History of the parish ... in Nasutów]). However, it is difficult to be absolutely sure, because Fr. Michał Słowikowski writes in his memoirs that Fr. Wyszyński "visited Kozłówka probably a year later [in 1942]; he was also at my place in Kamionka" ("Ks. Prałat M. Słowikowski”). Without new complementary data, this issue is difficult to resolve.

It is known that when the future Primate was hiding in Kozłówka, he used an assumed surname 'Okoński' and an alias 'Basia' (Gieroba 1). It was not until 2021, that, thanks to information contained in a recently discovered letter, it was possible to establish that Fr. Jan Poddębniak, who had been the chancellor and notary of the Bishop's Curia in Lublin since 1940, helped a young priest, unknown to himself at the time, who was being chased by the Gestapo, to obtain false documents of a deceased priest (Mackiewicz 12).

\footnotetext{
${ }^{5}$ These are the memories of Michał Żółtowski.

${ }^{6}$ A photo was attached to this page with the following caption: "The Palace in Nasutów during the Second World War, in which Fr. Okoński celebrated masses. It was rebuilt in the sixities, currently it houses the Cardinal Stefan Wyszyński Primary School."

${ }^{7}$ As was stated by the author: "Promotion of the book by Prof. Anna Łosowska 'Wierny Syn Ojczyzny naszej. Ksiądz Prałat Jan Poddębniak (1907-1994)' was unexpectedly enhanced with unknown facts from the clergyman's life." She further adds: "Canon Józef Chorębała, successor of Jan Poddębniak in Czemierniki (Radzyń district), while he was having a guest appearance at the book promotion, quoted some unknown, even sensational
} 
A hitherto unpublished letter was written by Maria Amerek (no date), twentyfour years ago, to Fr. Canon Józef Chorębała, successor of Jan Poddębniak in Czemierniki (Radzyń district). The author of the letter was the wife of Jan Amerk, a reserve lieutenant in the 25th Infantry Regiment, before the war a law graduate and employee of the Court of Appeal in Lublin, who died in Katyń. In the letter we find, among other things, the following information:

During that time [German occupation], His Excellency, Bishop Marian Leon Fulman was arrested by the Gestapo and imprisoned [in November 1939].

When the entire Curia was very deeply affected by this, expecting further arrests, a man came to the Curia, dressed as a worker, wearing rubber boots, very slim, tall and with an emaciated face - asking for a meeting with the Chancellor of the Curia. When before Fr. Canon Jan Poddębniak he revealed the purpose of his visit, namely asked for the papers of some deceased priest appropriate for his age.

The outraged Fr. Jan Poddębniak, sensing a German provocation - firmly refused his request.

The visitor was adamant, stating that he was a priest wanted by the Gestapo and such documents could, perhaps, save his life.

This made Fr. Poddębniak think that it could be a Silesian who spoke good Polish, but it could be a Gestapo mole and that it was linked to the arrest of Bishop Fulman.

Again, he refused very firmly.

The visitor did not relent. He kept repeating that he was a priest, that he was in hiding, that he had recently been working as a lumberjack, but that his lack of strength and health was forcing him to turn to the Curia for help, that he wanted to be treated, that he was ill with lung disease.

The very dignified attitude and beautiful Polish language used by the alleged worker puzzled Fr. Chancellor.

He began a conversation with an unexpected visitor on topics which are known to highly educated clergymen. He knew Latin and Greek.

$\mathrm{He}$ convinced Fr. Chancellor so much that (...) he gave appropriate false documents and intuitively sensed that it was indeed a Polish priest, hiding from the Gestapo.

He did not ask for the name - so as not to know anything. Handing in the papers he was asked for, he said for the first time, 'Father! - I have never given you these documents, you have never been to the Curia, you have never talked to me and even if the Gestapo cut me with a knife (...) and sprinkle me with salt during interrogation - we have never seen each other. Please remember this for the rest of your life.

God bless - and they parted.' (Private archive of Canon Józef Chorębała)

facts from the biography of Fr. Jan, which were not incorporated in the book. He himself learnt them from a letter which he had received 24 years before from an elderly lady who was closely related to the prelate. He had found this letter recently." 
September 1, 1941, the last day of Fr. Wyszyński's stay in Kozłówka, was dramatic but unexpectedly came to a happy end. That day, early in the morning, the news reached the palace that the German military police were about to launch a roundup. Some of the young men managed to hide, while the remaining inhabitants and guests, including Fr. Wyszyński, Countess Zamoyska and the Znamierowskis, were taken out to the meadows and surrounded by Germans who threatened to shoot them in retaliation for setting fire to the grain stacks. Then the unthinkable happened. Jadwiga Zamoyska, stepped out of line and in a firm tone, in flawless German, threatened the commander of the military police that he would pay with his head for shooting the gathered people. The Germans withdrew from the planned execution, releasing the detainees. Fr. Wyszyński decided that the situation was becoming increasingly tense and dangerous, and he did not want to put the owners of the palace at further risk with his own person, so he went to Nasutów in the evening of the same day (Niezwykty Gość 40). ${ }^{8}$

In many memoirs from the time of Fr. Wyszyński's stay in Kozłówka, the authors emphasise that even then he attracted attention with his unusual modesty, even asceticism, and charmed with his openness and naturalness. $\mathrm{He}$ was focused and serious, but with a cheerful smile. During scientific meetings and sermons preached with commitment, he willingly shared his profound knowledge (Niezwykty Gość 37-38, 42-43, 68, 69) gained during his studies at the Catholic University of Lublin, among others at the lectures of an expert on Catholic social science, Fr. Rector Antoni Szymański (Bender 77-78). "Steadfast in his principles of conduct and a "sower of unrest,' as he was dubbed" (Niezwykly Gość 65). It was not only with knowledge that he won the recognition and respect of those who met him. Krzysztof Znamierowski, who did altar serving, recalls the future Primate of the Millennium: "I sometimes watched his face askew, kneeling next to him during prayer. There was such clarity in him, such spirituality, such selfabsorption that sometimes it seemed to me that he had already left us, that he was where his prayers flowed" (Niezwykty Gość 51). Elsewhere, the same author writes that in 1941, he accompanied Fr. Wyszyński and Father, Prof. Znamierowski, on a walk from Kozłówka to Kamionka. During the conversation, at certain point, the latter stopped and, addressing the priest, uttered

\footnotetext{
${ }^{8}$ These are the memories of Monika Znamierowska-Kozik. See Byzdra-Kusz 61.
} 
the prophetic words, as it turned out years later: "After all, Reverend, you are already living in odore sanctitatis" (Niezwykty Gość 54). It took place exactly eighty years ago.

\section{BIBLIOGRAPHY}

“Adoracja Madonny.” Muzeum Zamoyskich w Kozłówce [The Zamoyski Museum in Kozłówka], www.muzeumzamoyskich.pl/matka-boska-kodenska. Accessed 7.07.2021.

Antoniuk, Grażyna. “Ksiądz Stefan Wyszyński w Kozłówce 1940-1941.”Lubartów i Ziemia Lubartowska, vol. 20, 2020, pp. 93-100.

Belina, Brzozowski, Antoni. Kozłówka w moich wspomnieniach. Muzeum Zamoyskich w Kozłówce, 1998.

Bender, Ryszard. "Naród i Ojczyzna w nauce i działalności Stefana Kardynała Wyszyńskiego Prymasa Polski." Roczniki Nauk Społecznych, vol. 10, 1982, pp. 77-87.

Byzdra-Kusz, Paulina. “'Kapłan silny duchem, wielkiego formatu' - ks. Stefan Wyszyński w Kozłówce." Przegląd Uniwersytecki, vol. 32, no. 4 (186), 2020, p. 60.

Czacka, Zofia. "Kozłówka - czas okupacji 1940-1945." Ateneum Kapłańskie, vol. 97, no. 2, 1981, pp. 321-327.

Czaczkowska, Ewa K. Kardynat Wyszyński. Świat Ksiązki, 2009.

Gieroba, Agnieszka. “'Basia’, czyli kp. Wyszyński w Kozłówce.” Gość Lubelski, no. 29, 2016, p. 1.

Glemp, Józef. "Świadectwo.” Studia Prymasowskie UKSW, vol. 4, 2010, pp. 61-63.

"Historia [parafii pw. Najświętszej Maryi Panny Królowej Polski w Nasutowie]." Parafia pw. Najświętszej Maryi Panny Królowej Polski w Nasutowie, parafianasutow.pl/historia/. Accessed 7.07.2021.

"Historia muzeum”. Muzeum Zamoyskich w Kozłówce [The Zamoyski Museum in Kozłówka], www. muzeumzamoyskich.pl/50-historia-muzeum. Accessed 7.07.2021.

"Historia parafii pw. Matki Bożej Anielskiej w Starościnie". Parafia pw. Matki Bożej Anielskiej w Starościnie, staroscin.diecezja.lublin.pl/historia.htm. Accessed 7.07.2021.

Jedynak, Marek. "Prymas Stefan Wyszyński i jego związki z Armią Krajową." Biuletyn IPN, no. 6 (175), 2020, pp. 25-26.

Kornacki, Krzysztof. “Znowu piękna.” Cenne Bezcenne Utracone, no. 1 (82)-2 (83), 2015, p. 17.

“'Kozłówka dla zakochanych' - spotkanie z Krzysztofem Kornackim” ['Kozłówka for lovers'meeting with Krzysztof Kornacki], Miejska Biblioteka Publiczna im. Adama Asnyka w Kaliszu [Municipal Adam Asnyk Public Library in Kalisz], archiwum.mbp.kalisz.pl/2009/ 090930_BG_K_Kornacki.htm. Accessed 7.07.2021.

“Ks. prałat M. Słowikowski - kapłan diecezji lubelskiej.” Bł. Kardynał Stefan Wyszyński. Blog, stefwysz.blogspot.com/2011/05/ks-praat-m-sowikowski-kapan-diecezji.html. Accessed 7.07 . 2021.

Mackiewicz, Monika. "Ksiądz, który ratował przyszłego prymasa Stefana Wyszyńskiego przed Gestapo."Wspólnota Radzyńska, 20 kwietnia 2021, p. 12.

Marciszuk, Teresa, editor. Rzemiosło artystyczne w zbiorach Muzeum Zamoyskich w Kozłówce. Nabytki 1956-1996. Muzeum Zamoyskich w Kozłówce, 1997. 
"Matka Boska Kodeńska." Muzeum Zamoyskich w Kozłówce [The Zamoyski Museum in Kozłówka], www.muzeumzamoyskich.pl/matka-boska-kodenska. Accessed 7.07.2021.

Micewski, Andrzej. Kardynat Wyszyński. Prymas i mąż stanu. Editions du Dialogue, 1982.

Niezwykły Gość, ed. Krzysztof Kornacki, Muzeum Zamoyskich w Kozłówce, 2000.

Ocalić od zapomnienia, ed. Łukasz Kacperek and Teresa Zambrzycka. [Niemce, s.n.], 2018.

Łoś, Piotr Szymon. "Pod gościnnym dachem Zamoyskich. Kozłówka w latach okupacji." Polskie Radio RDC. Radio dla Ciebie. www.rdc.pl/wp-content/uploads/2020/06/Pod-gościnnymdachem-Zamoyskim-POPR.pdf. Accessed 7.07.2021.

“Pokój księdza Stefana Wyszyńskiego.” Muzeum Zamoyskich w Kozłówce [The Zamoyski Museum in Kozłówka], www.muzeumzamoyskich.pl/Pokój\%20księdza\%20Stefana\%20Wyszyńskiego. Accessed 7.07.2021.

Private archive of Fr. Canon Józef Chorębała, parson in Czemierniki (Radzyń district), List od Marii Amerek [A letter from Maria Amerek] [no date].

Raina, Peter. Stefan Kardynat Wyszyński Prymas Polski. Oficyna Poetów i Malarzy, 1979-1995, 6 vols.

Report on the conversation 8.07.2021 with the former Director Krzysztof Kornacki - in the author's collection.

Report on the conversation 9.07.2021 with Grażyna Antoniuk (Department of Education, Museum Information and Publishing Houses) - in the author's collection.

Report on the conversation 9.07.2021 with the former chief stock taker Róża Maliszewska - in the author's collection.

"Służył tym, co miał." Apostolstwo Chorych, www.apchor.pl/temat/2020/06/14/Sluzyl-tym-co-mial. Accessed 7.07.2021.

Sulowski, Kacper. “To już 70 lat. Jak zmieniało się muzeum.” Gazeta Wyborcza, 5.07.2014, p. 36.

Świerdzewska, Irena. "Wojenne lata.” Idziemy, 30/2020, idziemy.pl/wiara/wojenne-lata/65094/2/. Accessed 7.07.2021.

Szczepaniak, Jacek. Pałac Zamoyskich w Kozłówce. Muzeum Zamoyskich w Kozłówce, 2008.

Wyszyński, Stefan. Nasz Ojciec Ksiądz Władysław Korniłowicz. Wydawnictwo Sióstr Loretanek, 1980.

\section{FATHER STEFAN WYSZYŃSKI'S \\ STAY WITH THE ZAMOYSKI FAMILY IN KOZŁÓWKA: A RECONSTRUCTION OF EVENTS AND PLACES}

\section{S u m m ary}

The article is an attempt to organize the existing knowledge about the stay of Fr. Stefan Wyszyński at the Zamoyski Palace in Kozłówka, where a state museum was opened after World War II. Almost half a century after the war, historical and museum research began on this subject. It was favored by the changing political situation and the publication of witnesses' memories. Late in the 1990s, the museum came up with the idea of commemorating the Primate of the Millennium in connection with the 60th anniversary of Fr. Wyszyński's stay at Kozłówka. At that time, a bust and a dedication plaque were unveiled to commemorate the Primate. The ceremonies were accompanied by the museum's publication Niezwykly Gość [Extraordinary Guest], containing recollections of the exceptional guest of Jadwiga and Aleksander Zamoyski. The next step taken by the Zamoyski Museum managers to commemorate Primate Wyszyński was the recon- 
struction of his room, ceremonially opened during the new exhibition "Father Stefan Wyszyński in Kozłówka 1940-1941" on June 21, 2016.

The reconstruction of the room was not an easy task for the museum staff, as neither the photos of the room nor the items related to Fr. Wyszyński were available. Some furniture from the nineteenth and early twentieth centuries was found in the museum's storage rooms. Several personal items that once belonged to the Primate were placed on the desk, such as a travel alarm clock and a set of writing utensils.

Translated by Stanistaw Sarek Proofread by Tomasz Patkowski

Keywords: Primate Stefan Wyszyński; Kozłówka; the Zamoyski family; World War II; museum.

\section{KSIĄDZ STEFAN WYSZYŃSKI U ZAMOYSKICH W KOZŁÓWCE. REKONSTRUKCJA WYDARZEŃ I MIEJSC}

Streszczenie

Artykuł jest próbą uporządkowania dotychczasowej wiedzy na temat ponadrocznego pobytu ks. Stefana Wyszyńskiego w pałacu Zamoyskich w Kozłówce, gdzie po II wojnie światowej zostało otwarte państwowe muzeum. Niemal pół wieku po zakończeniu wojny rozpoczęto badania historyczne i muzealne na ten temat. Sprzyjała temu zmieniająca się sytuacja polityczna, jak i wydawanie wspomnień przez świadków historii. W końcu lat dziewięćdziesiątych XX wieku, w muzeum pojawił się pomysł upamiętnienia postaci Prymasa Tysiąclecia w związku z przypadającym na rok 2000 sześćdziesięciolecie przyjazdu ks. Wyszyńskiego do Kozłówki. Wówczas odsłonięto popiersie i tablicę dedykacyjną, upamiętniającą postać Księdza Prymasa. Uroczystościom towarzyszyła muzealna publikacja Niezwykty Gość, zawierająca wspomnienia o wyjątkowym gościu Jadwigi i Aleksandra Zamoyskich. Kolejnym krokiem podjętym przez Dyrekcję Muzeum Zamoyskich, aby uczcić pamięć Prymasa Wyszyńskiego, była rekonstrukcja jego pokoju, uwieńczona uroczystym otwarciem 21 czerwca 2016 r. nowej ekspozycji „Ksiądz Stefan Wyszyński w Kozłówce 1940-1941".

Rekonstrukcja pokoju nie była łatwym zadaniem dla muzealników, gdyż nie zachowały się ani zdjęcia pomieszczenia, ani przedmioty związane z ks. Wyszyńskim. W muzealnych magazynach udało się znaleźć meble z XIX i początku XX wieku. Na biurku umieszczono kilka przedmiotów, które pozyskano, a które należały do Prymasa, m.in. budzik podróżny oraz komplet przyborów do pisania.

Słowa kluczowe: Ksiądz Prymas Stefan Wyszyński; Kozłówka; Zamoyscy; II wojna światowa; muzeum. 


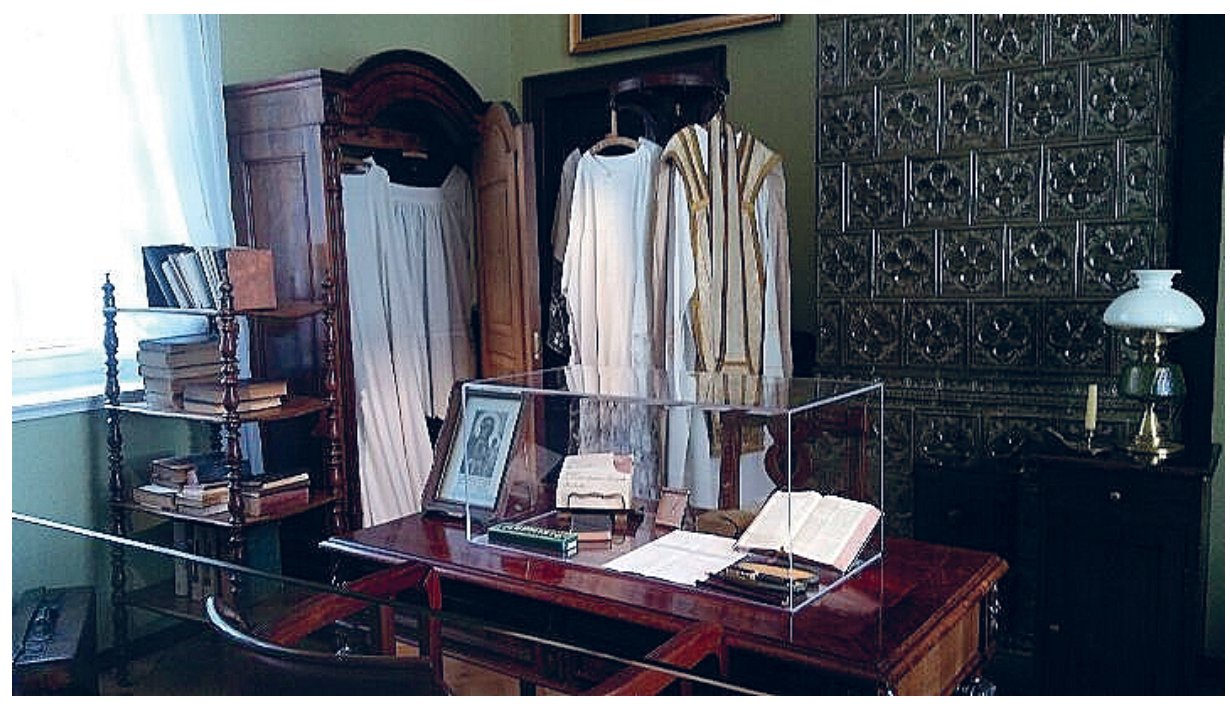

Photo 1. Room of Fr. Stefan Wyszyński in Kozłówka (photo by Agnieszka Bender)
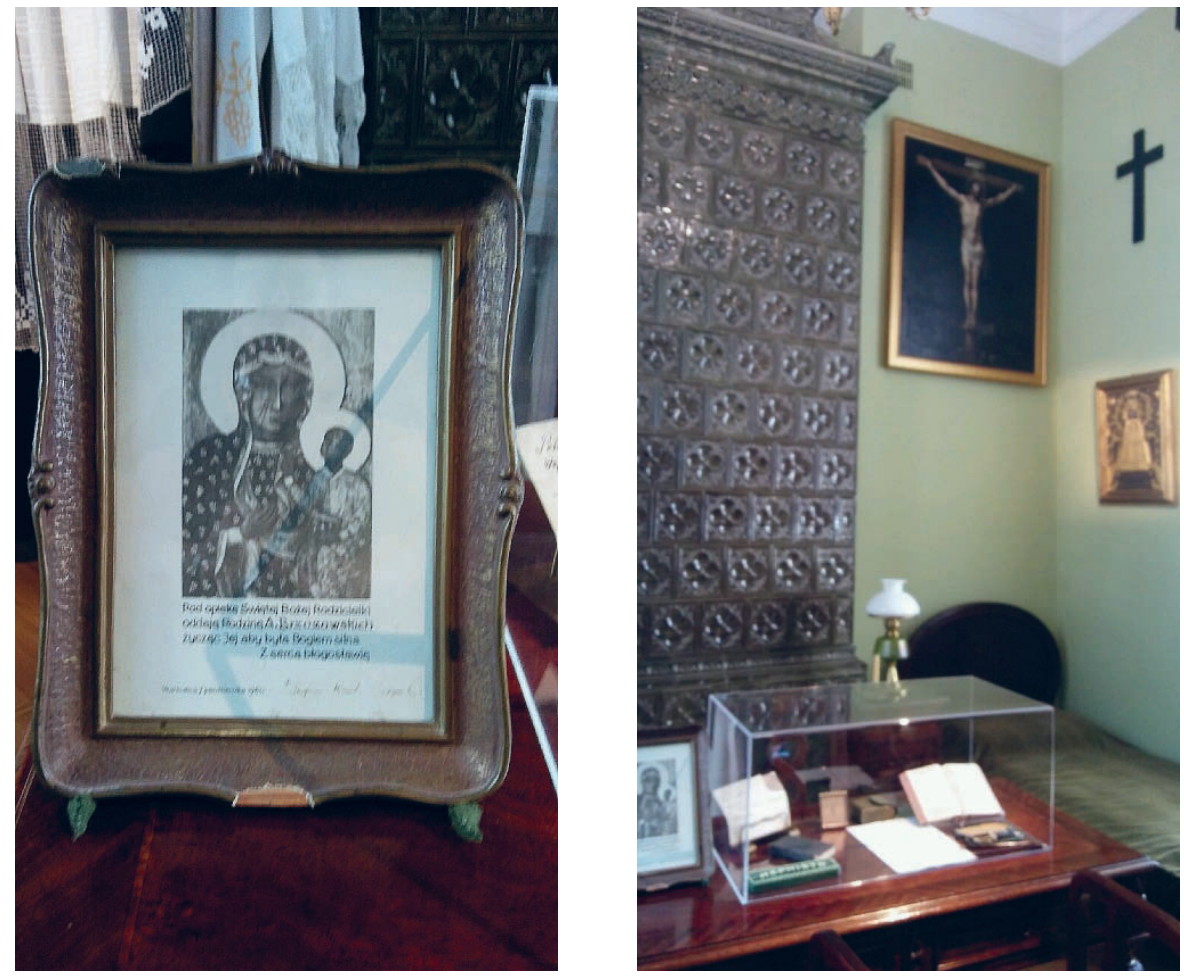

Photo 2 and 3. Other parts of the room (photos by Agnieszka Bender) 